\title{
COMPARISON ANALYSIS ON AWL OF THE ARTICLES IN INDONESIAN JOURNAL OF APPLIED LINGUISTICS AND OXFORD UNIVERSITY PRESS OF APPLIED LINGUISTICS
}

\author{
Mahsyurotun Nikmah \\ imafandi02@gmail.com \\ Universitas Airlangga
}

\begin{abstract}
This study focusses on comparing the utilization of Academic Word List (AWL) from the local and International journal articles. The articles that is in this study must meet two criteria. First, the articles should have open access articles. Eventually it is found the journal articles from Indonesian Journal of Applied Linguistics (IJAL) and Oxford University Press of Applied Linguistics (OUP) that provide the open access articles. Second, the articles should have the newest issues that have been published in the last two years. There are fifteen articles that have been chosen, and 507 academic word families of AWL from IJAL and 535 academic word of OUP were found. There are three steps to analyze the AWL of the journal articles, comprising the percentage, the differences and similarities and also the distribution of sub list AWL. The articles of IJAL have the percentage of AWL about 10,22\% but the OUP articles shows $11,41 \%$. There are 68 different of academic words from the articles of IJAL and OUP, the 20 words belong to IJAL and the other 48 words belong to OUP. Those different word are then occupied into the sub list AWL. It is found that the 20 AWL of IJAL journal only fill the sub list 9 and 10, while the 48 other AWL of OUP journal are categorized into sub list 2 up to sub list 10. It can be concluded that both of the journal articles of IJAL and OUP are categorized as academic journal.
\end{abstract}

Keywords: AWL; Indonesian Journal of Applied Linguistics; journal article; Oxford University Press of Applied Linguistics; Sub list-AWL

\begin{abstract}
Abstrak
Penelitian ini berfokus pada membandingkan pemanfaatan Daftar Kata Akademik $(A W L)$ dari artikel jurnal lokal dan internasional. Artikel-artikel yang dikaji dalam penelitian ini harus memenuhi dua kriteria. Pertama, artikel harus memiliki akses terbuka. Akhirnya ditemukan artikel jurnal dari Jurnal Linguistik Terapan Indonesia (IJAL) dan Oxford University Press of Applied Linguistics (OUP) yang menyediakan artikel-artikel dengan akses terbuka. Kedua, artikel harus membahas isu-isu terbaru yang telah diterbitkan dalam dua tahun terakhir. Ada lima belas artikel yang telah dipilih, dan ditemukan 507 keluarga kata akademik AWL dari IJAL dan 535 kata akademik pada OUP. Tiga langkah diambil untuk menganalisis AWL dari artikel jurnal, yakni terdiri dari persentase, perbedaan dan persamaan dan juga distribusi sub daftar AWL. Artikel-artikel di IJAL memiliki persentase AWL sekitar 10,22\% tetapi artikel OUP menunjukkan 11,41\%. Ada 68 kata akademik yang berbeda dari artikel IJAL dan OUP, 20 kata milik IJAL dan 48 kata lainnya milik OUP. Katakata yang berbeda tersebut kemudian ditempatkan ke dalam sub daftar AWL. Temuan dari analisis tersebut adalah 20 AWL jurnal IJAL hanya mengisi sub daftar 9 dan 10, sedangkan 48 AWL lainnya dari jurnal OUP dikategorikan ke dalam sub daftar 2 hingga sub daftar 10 Dapat disimpulkan bahwa artikel-artikel pada kedua jurnal, IJAL dan OUP, dikategorikan sebagai artikel jurnal akademik.
\end{abstract}

Kata kunci: AWL; Jurnal Bahasa Linguistik Terapan Indonesia; artikel jurnal; Oxford University Press of Linguistics Terapan; Sub-daftar-AWL 


\section{INTRODUCTION}

The demand of creating and publishing the academic article in higher education increasingly grow higher. In Indonesia, it is stated in the rules of the Minister of Administrative and Bureaucracy Reform number 17 asserted that scientific publication in national and international level must become an indispensable requirement of Tri Dharma as Higher Education activity (Permenpan, 2013). Beside that the Directorate General of Higher Education issued a Decision Letter number 152/E/T/2012 that is mandatory for all Indonesian postgraduate students to publish in International journals before they graduate (Dikti, 2016).

This study is expected to help the authors of academic article as the references in compiling the appropriate academic article. Since one of the requirements of writing the academic article is providing the article with academic word list. The Academic Word List (AWL) - from a corpus of 3.5 million written academic words outside the first 2000 most frequent English words (GSL). Coxhead (2000) emphasized the fact that the 570 items in the AWL covers about $10 \%$ of tokens in academic passages but only $1.4 \%$ of the tokens in fictional texts as proof that the list contains predominantly academic words. The AWL has, in return, been a reference and point of departure for many EAP vocabulary textbooks and exercises and continued to encourage and inspire further research (Farjami, 2013).

The aim of this study is to identify the utilization of Academic Word List (AWL) percentage of Indonesian Journal of Applied Linguistics (IJAL) and Oxford University Press of Applied Linguistics (OUP). After knowing the percentage of the AWL it would be known which journals is more academic but it is not the main indicator that the journal articles is categorized as the academic article. The next step is comparing the Academic Word List of journal article from IJAL and OUP by finding the similarity and differences of the AWL of those journal articles.

Besides that, this study also focusses on analyzing the distribution of Sub list AWL. The Academic Word List, compiled by Coxhead (2000), consists of 570-word families that are not in the most frequent 2,000 words of English but which occur reasonably frequently over a very wide range of academic texts. These 570 words are grouped into ten sub lists that reflect word frequency and range (Kinsella, 2003).

In selecting the words to be used in academic writing, several authors have chosen the Academic Word List created by Coxhead (2000). Coxhead (2000) compiled 414 academic texts of more than 400 authors, comprising 3,513,330 tokens or running words and 70,377 types (individual words) in approximately 11, 666 pages of text. To formulate this AWL, Coxhead filtered her word list with the word occurring in the GSL (General Service List). After filtering the words with the GSL, Coxhead finally concluded that there 570 word families that play significant roles in academic texts (Kwary , Deny A.; Artha, Almira F., 2017). 
The other researcher also had conducted the analysis on Academic Word List, such as Kwary, et al (2017) found several Academic Word List for Social Science (AWL-SS). The data was found from journals that provide open access article and the article must be from a journal that has a 5 -year impact factor. From the 237 journal titles in social science, it has founded 122 journal titles. From these 122 journal titles, the authors selected only one article that represent the title equally in the corpus. The final result it has founded 1,040,259-word tokens and it shows that the AWL-SS only consist of 350-word families.

Another research had been conducted by Farjami (2013) who had focus on surveying the abstracts of major articles in leading applied linguistics journals, published 2005 up to November 2011. The output includes a list of the most frequent content words, lists of frequent words and abbreviations not found in the British National Corpus. The study also weighed applied linguistics abstracts against the General Service List and the Academic Word List and identified words in these abstracts which are shared by the GSL or the AWL or are unique to one set. The report separately lists words from the GSL and the AWL which are proportionally more frequent in these abstracts than in general written texts, and hence may be reasonably regarded as playing key textual roles in applied linguistics abstracts and, by extension, discourse.

The gap of this study with the previous is on the way in analyzing the academic word list in the journal articles. This study focusses on comparing the academic word list of the same sciences based on the journal publishers that are from Indonesian Journal of Applied Linguistics and Oxford University Press of Applied Linguistics. IJAL represents the local journal publisher while OUP represents the International journal publisher. Meanwhile the previous study does not focus on the journal publisher. The finding of this study will help the reader as the references how is the utilization of academic word list of the journal articles from both journal publishers.

\section{METHOD}

The goal of this study was to compare the utilization of Academic Word List from journal articles of Indonesian. The corpus of this study is derived from the selected articles of Indonesian Journal of Applied Linguistics and Oxford University Press of Applied Linguistics. Journal of Applied Linguistics (IJAL) and Oxford University Press of Applied Linguistics (OUP). IJAL is chosen for this study because it represents the local journal of Indonesia that have been indexed by Scopus as well as OUP of England which represent the International Journal. Those journals have become reputable journal in their country.

The articles that would be downloaded from the internet must meet two criteria. First, the articles should have open access articles since it complies with the copyrights issues as the requirement of writing the academic article. Second, the articles should 
have the newest issues that have been published in the last two years. It has been downloaded 15 articles from Indonesian Journal of Applied Linguistics as well as 15 articles from Oxford University Press of Applied Linguistics.

The journal articles that have been downloaded from IJAL and OUP are in the form of PDF file. Then the author converting those articles into txt file manually using the software of pdf to txt (pdftotext.com/id) to lead the next step. After converting the 30 articles into txt file, then the writer input the 15 articles in the software called AntWordProfiler (Anthony, 2014).

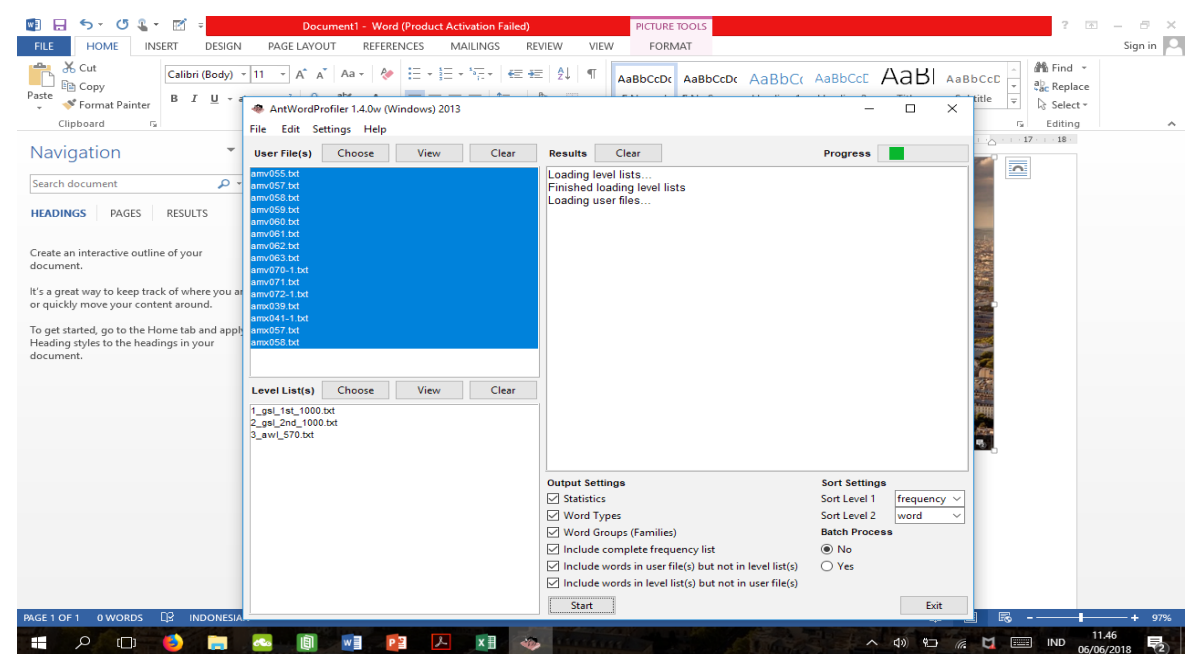

Figure 1. AntWordProfiler (Anthony, 2014)

After processing the articles using AntWordProfiler and founding the data, then the writer copies it into Microsoft Excel to be analyzed exhaustively. In analyzing the percentage and other calculation of AWL from IJAL and OUP, the writer needs the software of AntWordProfiler. While in comparing the example of utilization of specific word, the writer needs the software of AntConc to use the concordance feature. It will help the writer to give the evidence of utilization of specific word in a sentence.

\section{RESULT AND DISCUSSION}

As any result of converting the software, it can be obtained the following result. The following tables shows the result of the Academic Word List (AWL) of journal articles from Indonesian Journal of Applied Linguistics (IJAL) and Oxford University Press of Applied Linguistics (OUP). 
Table 1. The Percentage of Academic Word List of IJAL

$\begin{array}{cccccccccc}\text { FILE } & \text { TOKEN } & \begin{array}{c}\text { TOKEN } \\ \%\end{array} & \begin{array}{c}\text { CUM- } \\ \text { TOKEN }\end{array} & \text { TYPE } & \begin{array}{c}\text { TYPE } \\ \%\end{array} & \begin{array}{c}\text { CUM- } \\ \text { TYP }\end{array} & \text { GROUP } & \begin{array}{c}\text { GROUP } \\ \%\end{array} & \begin{array}{c}\text { CUM- } \\ \text { GROUP }\end{array} \\ \text { 1_gsl_1st_1000.txt } & 66472 & 68,47 & 68,47 & 2032 & 24,5 & 24,5 & 857 & 14,31 & 14,31 \\ \text { 2_gsl_2nd_1000.txt } & 4562 & 4,7 & 73,17 & 751 & 9,06 & 33,56 & 408 & 6,81 & 21,12 \\ \text { 3_awl_570.txt } & 9922 & 10,22 & 83,39 & 1294 & 15,6 & 49,16 & 507 & 8,47 & 29,59 \\ \text { - } & 16130 & 16,61 & 100 & 4216 & 50,84 & 100 & 4216 & 70,41 & 100 \\ & & & 97086 & & & 8293 & & & 5988\end{array}$

Table 2. The Percentage of Academic Word List of OUP

$\begin{array}{cccccccccc}\text { FILE } & \text { TOKEN } & \begin{array}{c}\text { TOKEN } \\ \%\end{array} & \begin{array}{c}\text { TOKEN } \\ \%\end{array} & \text { TYPE } & \begin{array}{c}\text { TYPE } \\ \%\end{array} & \begin{array}{c}\text { CUM- } \\ \text { TYPE }\end{array} & \text { GROUP } & \begin{array}{c}\text { GROUP } \\ \%\end{array} & \begin{array}{c}\text { CUMOUP } \\ \text { GROU }\end{array} \\ \text { 1_gsl_1st_1000.txt } & 94831 & 65,29 & 65,29 & 2284 & 20,39 & 20,39 & 879 & 10,58 & 10,58 \\ \text { 2_gsl_2nd_1000.txt } & 5869 & 4,04 & 69,33 & 906 & 8,09 & 28,48 & 465 & 5,6 & 16,18 \\ \text { 3_aw1_570.txt } & 16570 & 11,41 & 80,74 & 1581 & 14,12 & 42,6 & 535 & 6,44 & 22,62 \\ - & 27980 & 19,26 & 100 & 6429 & 57,4 & 100 & 6429 & 77,38 & 100 \\ & & & 145250 & & & 11200 & & & 8308\end{array}$

\section{The Percentage of Academic Word List Between IJAL and OUP}

Based on the data shown above, IJAL have the percentage of $10,22 \%$ and OUP have the percentage about $11,41 \%$. It indicates that both of the journal articles of IJAL and OUP can be categorized as Academic Article. Since it has been stated that the percentage of AWL must be approximately $9 \%$ that indicate the article has fulfilled the criteria of academic article. This academic word list of Coxhead makes up about $9 \%$ of the running words in the text (Nation, 2001). Meanwhile from the percentage of AWL usage, journal articles of OUP is higher rather than journal articles of IJAL.

From 15 journal articles of Indonesian Journal of Applied Linguistics (IJAL) it contains 9922 token words of AWL and it has been categorized into 507-word families, while Oxford University Press of Applied Linguistics (OUP) contains 16570 token words of AWL and it has been categorized into 535word families. The difference of Academic Word List (AWL) of IJAL and OUP are about 28 words. In terms of quantity of AWL, OUP have more number of academic words rather than IJAL since it probably caused by the high number of token words.

On the other way the Type Token Ratio (TTR) of AWL from IJAL is about $0,13 \%$, while the TTR of AWL from OUP is about $0,09 \%$. From those number, it can be revealed that the variation of Academic Word List of IJAL is higher rather than 
OUP.

\section{The Similarities and Differences of Academic Word List of IJAL and OUP}

It has been stated above that the AWL of IJAL is 507 while the AWL of OUP is 535. From those AWL, the writer then sorts out the identical words of both journals. In comparing the journal of IJAL and OUP, it is founded that there are 487 words that are similar from journal articles of IJAL and OUP. And the total of different words from IJAL and OUP are 68 words. The 68 words can be divided into two groups, 20 words belong to IJAL and 48 words belong to OUP since the OUP have more amount of AWL rather than IJAL so the number of distinctions is higher. Here are the tables regarding the similar words that frequently used in IJAL and OUP.

Table 3. The highest range of similar AWL from IJAL and OXAL journal articles

\begin{tabular}{|c|c|c|c|}
\hline \multicolumn{2}{|c|}{ IJAL } & \multicolumn{2}{c|}{ OUP } \\
\hline TYPE & RANGE & TYPE & RANGE \\
\hline abstract & 15 & Research & 15 \\
\hline conclude & 15 & Journal & 15 \\
\hline Journal & 15 & conclude & 15 \\
\hline research & 15 & abstract & 15 \\
\hline
\end{tabular}

The column of Range above shows the amount of usage or appearance of AWL in the article. If it is stated 15, it indicates that all of the article uses those words. The similar 487 words that found in journal article of IJAL as well as OUP, it has been ranked the highest range of both journals. The table above shows there are only 4 similar words that appear in all of the journal articles of IJAL and OUP. Those words are abstract, research, conclude and journal.

Those words (abstract, research, conclude and journal) appear frequently in all of the articles since most of the article must contain those kinds of word. Meanwhile those articles are academic article that somehow need to conduct the research before writing the article. And of course, in writing the academic article it needs abstract, conclusion and also references from several previous articles.

In terms of the different academic word list, the writer found several words in journal articles of IJAL and OUP. The different academic word list of both IJAL and OUP is listed in the following table. 
Table 4. The highest range of different AWL of journal articles of IJAL and OUP

\begin{tabular}{|c|c|c|c|}
\hline \multicolumn{2}{|c|}{ IJAL } & \multicolumn{2}{c|}{ OUP } \\
\hline TYPE & RANGE & TYPE & RANGE \\
\hline Finance & 4 & grant & 8 \\
\hline Inspect & 2 & inherent & 9 \\
\hline Prohibit & 2 & sole & 8 \\
\hline Rigid & 3 & subsequent & 8 \\
\hline
\end{tabular}

Table 4 above shows the highly used words of different AWL from Journal articles of IJAL and OUP. It stated that there are several different AWL of IJAL such as finance, inspect, prohibit, and rigid. While it also found several AWL of OUP that is different from IJAL, such as grant, inherent, sole, and subsequent. The writer will choose the highest range as the evidence using the AntCont Software as concordance approach.

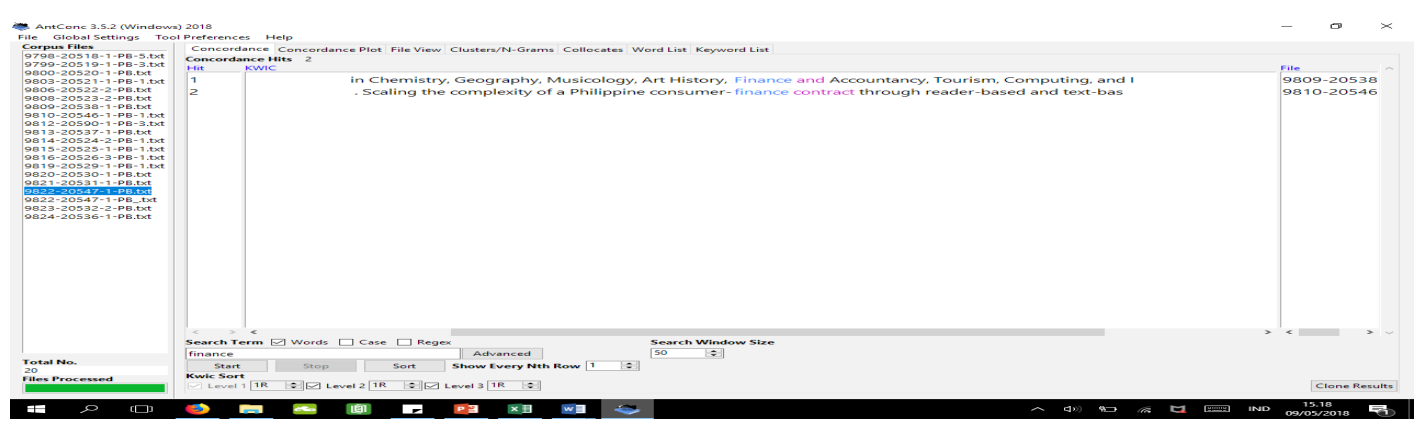

Figure 2. The concordance of the word finance

As stated above that there are several AWL found in IJAL that is different from OUP, the writer choose one evidence (i.e. finance). Figure 2 shows the result of concordance of finance which is used in the article.

In oxford dictionary, the word finance is identified as the management of large amounts of money, especially by governments or large companies. Or it can be defined as Provide funding for (a person or enterprise). First article indicates finance as one of the majors in the university that has been chosen by the author (Lo, Yueh) as the object of doing the research. Since the research is about ESL teacher willingness to communicate in English. She chooses several students from different major as her object of conducting research. The second article indicating finance as the title of the article that the author (Rosa, J. Paul) has used as one of his references.

The following figure 3 reveals one evidence (i.e. inherent) found in OUP that is different from IJAL. The writer also discovers the concordance usage of inherent in the article. 


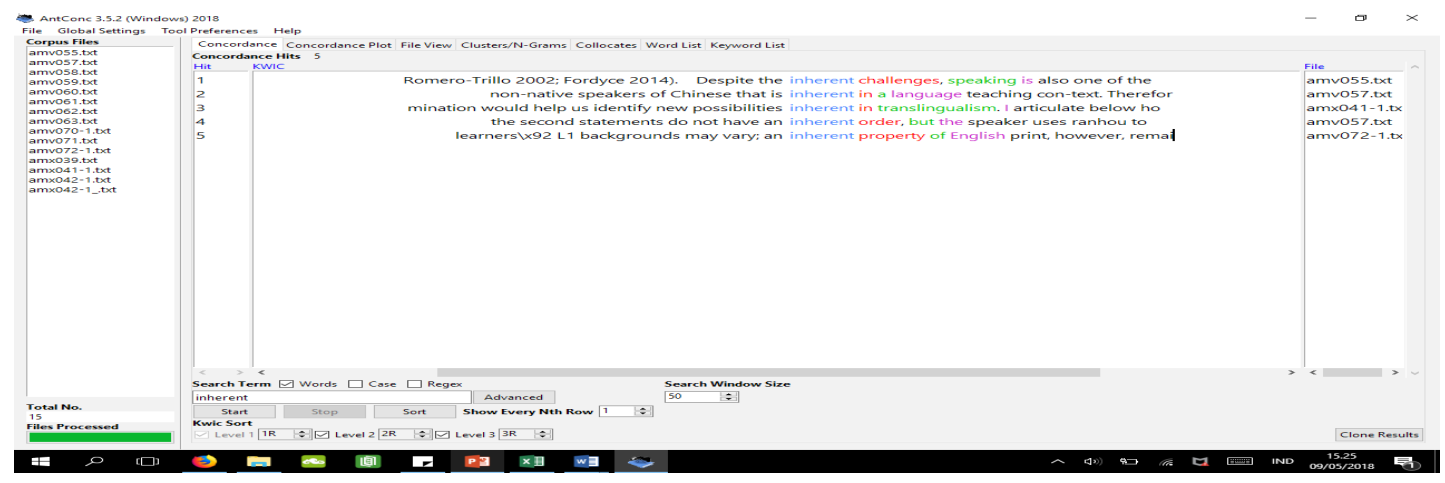

Figure 3. The concordance of the word inherent

The definition of inherent in Oxford Dictionary is defined as existing in something as a permanent, essential, or characteristic attribute. In the software above there are 5 evidence which using the word inherent. The first evidence of inherent utilization used by the author Gablasova, D. It may indicate the inherent challenges, which may mean as the essential challenges.

\section{The Distribution of Sub list Academic Word List of IJAL and OUP}

After defining the similarity and also the differences of AWL that provide in journal articles of IJAL and OUP, the writer then compiling the AWL into Sub list AWL. The academic word list that would be compiled is the different AWL (68 words) that indicates the deviation of academic word list from the Journal of IJAL and OUP. And it does not need to distribute the similar AWL of IJAL and OUP since it will be located in the same sub list.

The AWL contains 570-word families which were selected by analyzing a corpus of millions of words from over 400 academics texts. Words were taken from 28 different academic subject areas within the disciplines of Arts, Commerce, Law and Science, so they are relevant for all areas of academic study. The list of 570 words was then divided into ten sub lists, with the most frequent 60 words in Sub list 1, to the least frequent words in Sub list 10. The list excludes the most frequent 2000 words of English. A word like analyze falls into Sub list 1, which contains the most frequent words, while the word adjacent falls into Sub list 10 which includes the least frequent (amongst this list of high incidence and high utility words). The ten sub lists contain the headwords of the families in the Academic Word List. In other words, the ten sub lists contain the most frequent form of the word, more often a noun or verb form, although there may be one or more important related word forms. For example, the headword analyze would also include analyst, analytic, analytical and analytically in the word family. (Kinsella, 2003). 
It has been stated above that the differences of the AWL from journal articles of IJAL and OUP are 68 words. The writer then divides it into 2 tables and distribute the word into its Sub list AWL which is proposed by Kinsella (2003). The upper table indicates the 20 words with their sub list AWL of journal articles from IJAL. And the nether table indicates the 48 words with their sub list AWL of the journal articles from OUP. Searching the sub list AWL is aimed to reveal the word are categorized as Sub list 1, 2,3, or Sub list 10. It is aimed to know the used frequent word since the function of Sub list AWL is to know whether the AWL is frequently used or not.

Table 5. The category of Sub list-AWL of the AWL from journal articles of IJAL

\begin{tabular}{|c|c|}
\hline \multicolumn{2}{|c|}{ IJAL } \\
\hline TYPE & SUB LIST \\
\hline Allocate & 9 \\
\hline Assure & 9 \\
\hline Conform & 9 \\
\hline Deduce & 9 \\
\hline Eliminate & 9 \\
\hline Export & 9 \\
\hline Fee & 9 \\
\hline Finance & 9 \\
\hline Incentive & 9 \\
\hline Injure & 9 \\
\hline Inspect & 9 \\
\hline Offset & 9 \\
\hline prohibit & 9 \\
\hline Regime & 9 \\
\hline Rigid & 9 \\
\hline Tape & 9 \\
\hline voluntary & 9 \\
\hline Adjacent & 10 \\
\hline Depress & 10 \\
\hline Odd & 10 \\
\hline
\end{tabular}

From the table 5. it can be seen that most of the AWL from IJAL fill the sub list 9 and sub list 10. Those 17 words that fill the Sub list 9 and there are 3 words fill Sub list 10 . Sub list 9 and 10 indicates that high sub list or the words in this sub list is rarely used. It means that the AWL that used in journal article of IJAL is categorized as the non-frequent-used word. It indicates that the word which are used in IJAL Journal are 
categorized as the high word of AWL.

Table 6. The category of Sub list-AWL of the AWL from journal articles of OUP

\begin{tabular}{|c|c|c|c|}
\hline \multicolumn{5}{|c|}{ OUP } \\
\hline TYPE & SUB LIST & TYPE & SUB LIST \\
\hline Commission & 2 & Currency & 8 \\
\hline Credit & 2 & Displace & 8 \\
\hline Purchase & 2 & Fluctuate & 8 \\
\hline Coordinate & 3 & Plus & 8 \\
\hline Layer & 3 & Terminate & 8 \\
\hline Scheme & 3 & Thereby & 8 \\
\hline Grant & 4 & Analogy & 9 \\
\hline subsequent & 4 & Cease & 9 \\
\hline discrete & 5 & Commence & 9 \\
\hline energy & 5 & Compatible & 9 \\
\hline pursue & 5 & Inherent & 9 \\
\hline welfare & 5 & Military & 9 \\
\hline Estate & 6 & Portion & 9 \\
\hline Federal & 6 & Protocol & 9 \\
\hline Interval & 6 & Scenario & 9 \\
\hline Overseas & 6 & Sphere & 9 \\
\hline Underlie & 6 & Temporary & 9 \\
\hline Advocate & 7 & Collapse & 10 \\
\hline Chemical & 7 & Compile & 10 \\
\hline Guarantee & 7 & Enormous & 10 \\
\hline Release & 7 & Forthcoming & 10 \\
\hline Simulate & 7 & Integrity & 10 \\
\hline Sole & 7 & Notwithstanding & 10 \\
\hline Arbitrary & 8 & Panel & 10 \\
\hline
\end{tabular}

Table 6 shows the AWL of OUP which have been compiled into its sub list. From 48 words, it shows that there are 3 word that fill sub list 2, 3 words fill sub list 3 , 2 words fill sub list 4, 4 words fill sub list 5 and so on. The main point is Sub list 2 up to Sub list 10 is being filled with academic word of journal article of OUP. It indicates that the using of AWL from OUP journal is in the average for it fill almost all of the sub list range.

\section{CONCLUSION}

This study has shown the comparison of AWL from Indonesian Journal of Applied Linguistics and Oxford University Press of Applied Linguistics. From the percentage side, IJAL and OUP has fulfilled the criteria of academic article although the percentage of OUP is higher. While in the differences and similarities of AWL side, both journals have their own variation of AWL. And from the distribution of sub list 
AWL, both of the journals have fulfilled 10 sub list AWL. The 20 words of IJAL are occupied the Sub list 9 to Sub list 10, while the 48 words of OUP are only occupied from Sub list 2 up to Sub list 10.

In conclusion, both journal articles of Indonesian Journal of Applied Linguistics and Oxford University Press of Applied Linguistics have fulfilled the criteria of academic article although it is in different ways. It can be proved by the percentage of AWL, the differences and similarities of AWL, and also the distribution of sub list AWL.

As suggestion for the authors, we are supposed to sort out the journal articles not only based on the percentage of the AWL. Beside that we need to be aware with the other aspects before we judge that the specific journal article is more academic rather than the others. It could not be judged that IJAL as the local journal article is not qualified since some of the authors or the reviewers come from the overseas. Above all, the authors need to enrich their academic word in order to create the appropriate academic writing.

\section{REFERENCES}

Anthony, L. (2014). AntConc (Version 3.5.7) [Software]. Available from http://www. laurenceanthony.net/

Anthony, L. (2014). AntWordProfiler (Version1.4.1) [Software]. Available from http:// www.laurenceanthony.net/

Dikti. (2018). Surat Dirjen Dikti No. 152/E/T/2012: Wajib Publikasi Ilmiah Bagi S1/ S2/S3. Available from http://www.kopertis12.or.id

Farjami, H. (2013). A Corpus-Based Study of the Lexical Make-up of Applied Linguistics Article Abstracts. The Journal of Teaching Language Skills (JTLS).

Indonesian Journal of Applied Linguistics. (2018). (Journal Artcles). Available from http://ejournal.upi.edu/index.php/IJAL

Kinsella. (2003). The Academic Word List (Averil Coxhead, 2000):. San Fransisco State University (Handout).

Kwary, Deny A.; Artha, Almira F. (2017). The Academic Article Word List for Social Science. MEXTESOL Journal.

Nation, I.S. P. (2001). Learning Vocabulary in Another Language. Cambridge, UK: Cambridge University Press

Oxford University Press of Applied Linguistics. (2018). (Journal Articles). Available from https://academic.oup.com/applij

Permenpan. (2018). Peraturan Menteri Pendayagunaan Aparatur Negara dan Reformasi Birokrasi. Available from //www.kelembagaan.ristekdikti.go.id 
Mahsyurotun Nikmah

PDFtoTEXT. (2017). pdftotext [Software]. Available from pdftotxt.com/id 